\title{
SEAWEED EXTRACTS EXHIBIT ANTICANCER ACTIVITY AGAINST HeLa CELL LINES
}

\author{
ASHWINI S. ${ }^{1}$, SURESH BABUT V. ${ }^{2}$, SARITHA ${ }^{3}$, MANJULA SHANTARAM ${ }^{4}$ \\ Department of Studies in Biochemistry, Mangalore University, Post Graduate Centre, Chikka Aluvara, 571232, Kodagu, Karnataka, India \\ Email: manjula59@gmail.com
}

Received: 01 Oct 2016, Revised and Accepted: 05 Dec 2016

\begin{abstract}
Objective: This study was conducted to examine the anticancer activities in the extracts of marine seaweeds Gracilariacorticata.

Methods: The acetone, chloroform, ethanol, methanol and aqueous extracts of collected seaweeds were tested for their anticancer properties in vitro against HeLa cancer cell lines.

Results: The anticancer activity of the seaweed extracts was observed at 24 hours, 48 hours and $72 \mathrm{~h}$ in which chloroform and ethanol extracts of $G$. corticata showed a greater activity with an $\mathrm{IC}_{50}$ value of $341.82 \mu \mathrm{g} / \mathrm{ml}$ and $244.7 \mu \mathrm{g} / \mathrm{ml}$ respectively for 48hours. $P$-values were determined by twoway analysis of variance (ANOVA). The morphology of the treated cells showed a great variation when compared to the control cells. Thus, the in vitro assay indicates that the extracts of seaweeds are the significant source of a noble anticancer agent.
\end{abstract}

Conclusion: This study also infers that $G$. corticata could be a potential candidate for cancer therapy in the near future.

Keywords: Seaweeds, Cytotoxicity, HeLa cell lines, Anticancer

(C) 2016 The Authors. Published by Innovare Academic Sciences Pvt Ltd. This is an open access article under the CC BY license (http://creativecommons.org/licenses/by/4.0/)

DOI: http://dx.doi.org/10.22159/ijcpr.2017v9i1.16632

\section{INTRODUCTION}

Marine algae (Seaweeds) are a group of marine multicellular algae having various health benfits and biomedical applications in the marine ecosystem. Seaweeds are immensely potential as a supplement in functional food and for the extraction of compounds. They are well known for their richness in minerals, certain vitamins and polysaccharides, but they also contain bioactive substances like proteins, lipids and polyphenols, with antibacterial, anticancer, antioxidant, antifungal, antiviral properties and so on $[1,2]$.

Seaweeds, which are abundant sources of bioactive components, have gained much importance and interest in recent times. The complex polysaccharides from the brown, red and green seaweeds possess broad spectrum therapeutic properties. The marine environment contains a different number of plants, animals and microorganisms which have a wide range of natural products.

The well documented bioactive metabolites of marine algae include brominated phenols [3], sterols, amino acids and amines [4] and sulphated polysaccharides [5-7]. Recent findings evidenced that seaweeds contained antiviral [8], antibacterial [9], antifungal [10] and anti-tumoral [11] potentials, among numerous others. As an essential goal to lower side effects on immune system, the discovery and identification of new antitumor drug from natural resources have become necessary [12]. Some researchers have described a wide range of biological activities for algal compounds including anti-HIV, anticoagulant, anticonvulsant, anti-inflammatory, bacteriostatic, antineoplastic, and cytotoxic activities [13].

Hundreds of potential anti-tumor agents have been isolated from marine origin especially from marine algae $[14,15]$. Isolation of cytotoxic anti-tumor substances from marine organisms has been reported by several authors during the last 40 y [16]. In this study, the in vitro antitumor activity of Gracilariacorticata a red alga which is found in many parts of the world such as China sea, Indian Ocean, Persian Gulf was determined.

\section{MATERIALS AND METHODS}

Collection of seaweed sample

Seaweeds were collected from the rocks of Surathkal beach $(13$ $00^{` 34.1 " N}$ lat. and 74 47`16.1" E long.), Dakshina Kannada district,
Karnataka. Samples were washed with freshwater to remove adhering debris and identified as Gracilaria sp. By Dr. C. R. K Reddy, CSIR-Central Salt and Marine Chemicals Research Institute. The collected samples were transferred to the lab in a polythene bag, shade dried and powdered.

\section{Seaweed extraction}

Fifty grams of powdered seaweed was extracted successively using Soxhlet extractor sequentially with different solvents of increasing polarity namely: chloroform, acetone, methanol, ethanol, and water until the extract was clear. The resulting pasty extracts were stored in a refrigerator at $4{ }^{\circ} \mathrm{C}$ for future use.

\section{Cancer cell line and chemicals}

Cancer cell line HeLa was purchased from National Centre for Cell Science (NCCS), Pune, India. Dulbecco's Modified Eagle's Medium (DMEM), Trypsin-EDTA, Fetal Bovine Serum (FBS), 3-(4, 5dimethylthiazol-2yl)-2, 5-diphenyltetrazolium bromide (MTT), sodium bicarbonate, Dimethyl sulphoxide (DMSO) and antibiotic solution were purchased from Himedia. 96 well plates, 6 well plates, Tissue culture flasks ( 25 and $75 \mathrm{~mm}^{2}$ ), centrifuge tubes (15 and 50 $\mathrm{ml}$ ) were purchased from Himedia.

\section{In vitro assay for cytotoxicity activity (MTT assay)}

HeLaHuman cervical cancer cell lines obtained from (NCCS) Pune were maintained in RPMI-1640 supplemented with $10 \%$ FBS, penicillin $(100 \mathrm{U} / \mathrm{ml})$ in a humidified atmosphere of $50 \mu \mathrm{g} / \mathrm{ml} \mathrm{CO}_{2}$ at $37^{\circ} \mathrm{C}$.

In vitro assay for cytotoxic activity of investigated extract was performed when the cells reached $70-80 \%$ of cofluence [17]. A stock solution of the extract was dissolved in the corresponding medium to the required working concentrations.200 $\mu$ l cell suspension was seeded in a 96-well plate at required cell density $(20,000$ cells per well), without the test agent. The cells were allowed to grow for about $12 \mathrm{~h}$. Then, cells were incubated in the presence of various concentrations of the samples $(50,100,150$, $200,250 \mu \mathrm{g} / \mathrm{ml}$ ) for 24 hours, 48 hours and 72 hours at $37^{\circ} \mathrm{C}$ in $5 \%$ $\mathrm{CO}_{2}$ atmosphere. The effect on cancer cell survival was determined 24hours, 48 hours and72 $\mathrm{h}$ after the addition of extract, by the MTT test. Standard drug Berberine was used as a positive control. 
Briefly, $20 \mu \mathrm{L}$ of MTT solution ( $5 \mathrm{mg} / \mathrm{ml}$ of total volume) was added to each well and incubated for a further $3 \mathrm{~h}$ at $37^{\circ} \mathrm{C}$ in $5 \% \mathrm{CO}_{2}$ and humidified the air. Subsequently, $100 \mu \mathrm{l}$ of solubilization solution (DMSO) was added to solubilize the formazan crystals formed from MTT after the conversion by mitochondrial dehydrogenases of viable cells. Gentle stirring in a gyratory shaker was done to enhance dissolution. Viable cells were determined by the absorbance at 570 $\mathrm{nm}$ with reference at $655 \mathrm{~nm}$. Measurements were performed 3 times, and the concentration required for a $50 \%$ inhibition of viability $\left(\mathrm{IC}_{50}\right)$ was determined graphically. The absorbance at 570 $\mathrm{nm}$ was measured with an ELISA reader. All experiments were performed in triplicate. The effect of the seaweed extracts on the proliferation of human cervical cancer cells was expressed as the $\%$ cell viability, using the following formula:

$\%$ Cell viability $=$ A570 of treated cells $/$ A570 of control cells $\times 100 \%$.

\section{Morphological changes}

The plates were observed under an inverted microscope (Biolink) to detect morphological changes. The result showed that HeLa cell proliferation was significantly inhibited by the seaweed extracts. These results indicate that the sensitivity of human cervical cancer cell line for cytotoxic drugs was higher for chloroform and ethanol extracts compared to other extracts.

\section{Data analysis}

The $\mathrm{IC}_{50}$ values (concentration at which $50 \%$ of cells were dead) are reported as mean \pm standard deviation of three independent experiments. The $\mathrm{IC}_{50}$ values against the HeLa cancer cell lines were calculated for all the seaweed extracts inhibiting at least 50\% inhibition when tested at concentration. Two-way analysis of variance (ANOVA) was used to compare data using GraphPad Prism version 5.0 software at a $95 \%$ confidence limit.

\section{RESULTS AND DISCUSSION}

Antitumor activity of seaweed extracts and in vitro cytotoxic effect of extracts on HeLa cells

To examine potential cytotoxic effects of seaweed extracts on human cervical cancer cell lines, they were cultured for 24 hours, $48 \mathrm{~h}$ and72 $\mathrm{h}$ at various concentrations of alga extract and analysed by MTT assay (fig. 1, 4). The activity against cancer cell lines is one of the most important specificities of marine algae, and many algae have shown cytotoxic and antitumor activities. In this study, the extracts of Gracilariacorticata showed a significant number of cell death of HeLa cells. The percentage of viable cells was calculated using the formula based on which the $\mathrm{IC}_{50}$ value of chloroform extract was found to be $341.82 \mu \mathrm{g} / \mathrm{ml}$ (fig. 2a), IC 50 value of ethanol extract was found to be $244.7 \mu \mathrm{g} / \mathrm{ml}$ (fig. $2 \mathrm{~b}$ ) for 48hours. Morphological changes were determined by inverted microscope (fig. $3 a, 3 b, 3 c$ and $3 d$ ).

It has previously been reported that lophocladines, naphthyridine alkaloids, isolated from the marine red alga Lophocladiasps. has exerted inhibitory effects on NCI-H460 lung cancer cells [18]. Several cytotoxic compounds such as fucoidans, laminarians, and terpenoids stated to possess anticancer, antitumor, and antibacterial and antiproliferative properties are reported to be abundant in seaweeds [19]. Hence, in recent years, the search for the cancer therapeutics from natural products has been on the rise. Bioactive compounds in marine plants have been reported against various cancer cell lines.

\section{MTT ASSAY}

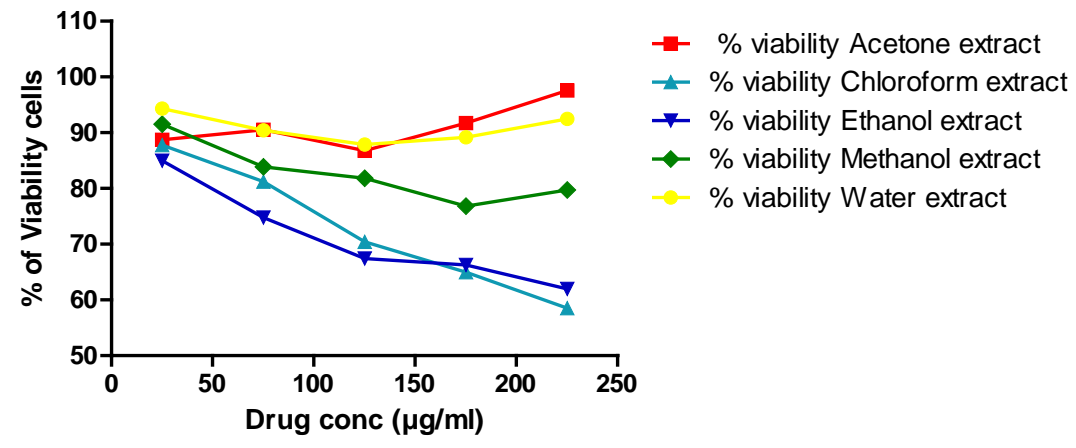

Fig. 1:
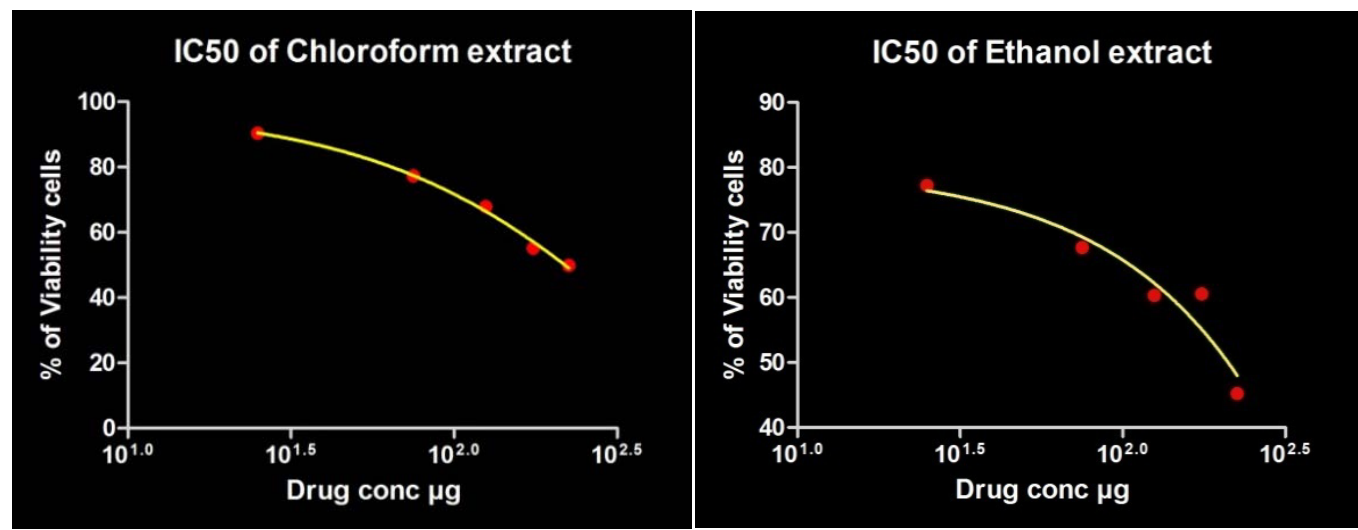

Fig. 2(a-b)

\section{Morphological study}

Upon treatment with five different seaweed extracts, a morphological observation of the HeLa cell lines shows the onset of shrinkage.
The cell shrinkage increased progressively with dose and time, and this shrinkage may be due to the growth inhibitory effect of seaweeds. 

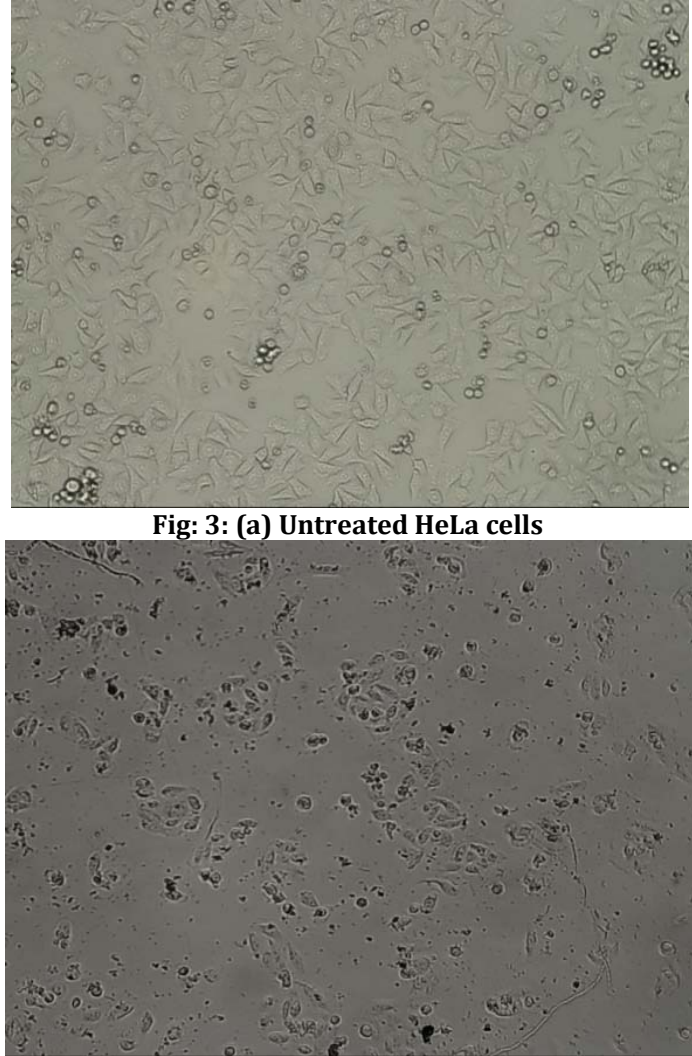

Fig: 3: (c) Ethanol extract treated cells

\section{MTT ASSAY AGAINST HeLa CELL LINES}

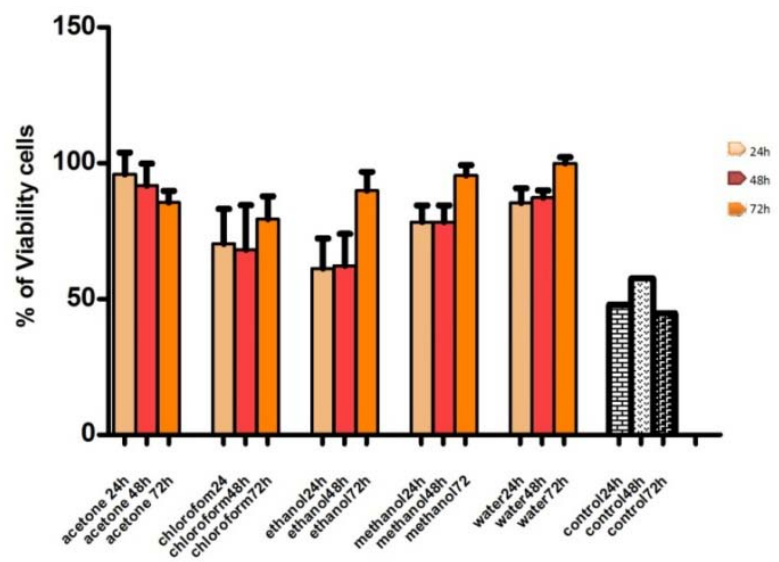

Fig. 4: Bars represent mean cell viability normalised to untreated control cells and error bars indicate SD of three independent experiments

\section{CONCLUSION}

Cancer is a group of diseases which is characterised by uncontrolled growth and spread of abnormal cells. The spread of these abnormal cells must be controlled, failing may result in death. Despite considerable progress in research, cancer remains one of the highranking causes of death in the world. As an urge to study the effect of the extracts of marine alga Gracilariacorticata as a novel therapeutic agent, they were characterised for their cytotoxic effects against HeLa (human cervical cancer) cell lines. To conclude, this extract induces a concentration-dependent inhibition of cells. Based on these results, further studies could be carried out as a search for new compounds from red algae to develop alternative therapeutic measures against diseases.

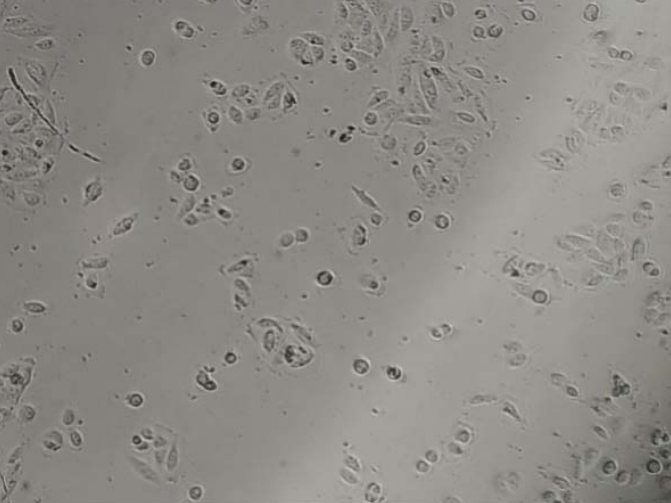

Fig: 3: (b) Chloroform extract treated cells

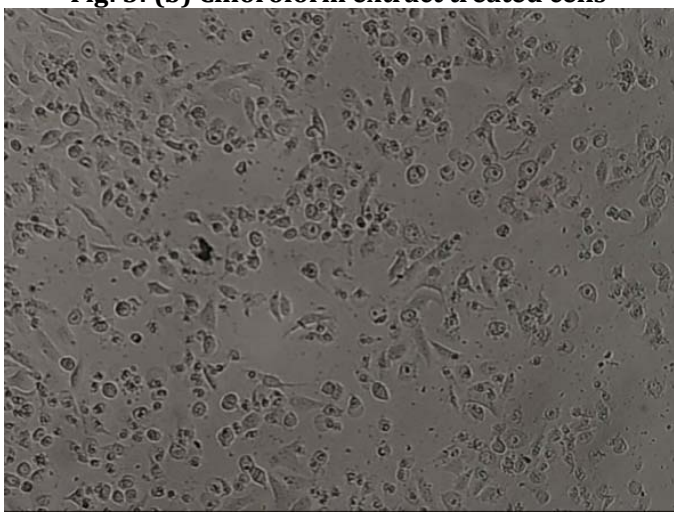

Fig: 3: (d) Berberine extracts treated cells

\section{ACKNOWLEDGEMENT}

Authors would like to thank Mangalore University for their support and encouragement

\section{CONFLICT OF INTERESTS}

Declared none

\section{REFERENCES}

1. Chandini SK, Ganesan P, Suresh PV, Bhaskar N. Seaweeds as a source of nutritionally beneficial compounds-a review. J Food Sci Technol 2008;45:1-13.

2. Holdt SL, Kraan S. Bioactive compounds in seaweed; functional food applications and legislation. J Appl Phycol 2011;23:543-97.

3. Liu M, Hansen PE, Lin X. Bromophenols in marine algae and their bioactivities. Mar Drugs 2011;9:1273-92.

4. Kim SK, Ta QV. Potential beneficial effects of marine algal sterols on human health. Adv Food Nutr Res 2011;64:191-8.

5. Misurcova L, Skrovankova S, Samek D, Ambrozova J, Machu L. Health benefits of algal polysaccharides in human nutrition. Adv Food Nutr Res 2012;66:75-145.

6. Jimenez-Escrig A, Gomez-Ordonez E, Ruperez P. Seaweed as a source of novel nutraceuticals: sulphated polysaccharides and peptides. Adv Food Nutr Res 2011;64:325-37.

7. Kim SK, Li YX. Medicinal benefits of sulfated polysaccharides from sea vegetables. Adv Food Nutr Res 2011;64:391-402.

8. Matsuhiro B, Conte AF, Damonte EB, Kolender AA, Matulewicz MC, Mejias EG, et al. Structural analysis and antiviral activity of a sulfated galactan from the red seaweed Schizymeniabinderi (Gigartinales, Rhodophyta). Carbohydr Res 2005;340:2392-402.

9. Xu N, Fan X, Yan XJ, Li X, Niu R, Tseng CK. Antibacterial bromophenols from the marine red alga Rhodomelaconfervoides. Phytochemistry 2003;62:1221-4.

10. Li XC, Jacob MR, Ding Y, Agarwal AK, Smillie TJ, Khan SI, et al. Capstones $\mathrm{A}$ and $\mathrm{B}$, which enhance fluconazole activity in Saccharomyces cerevisiae, from the marine green alga, Penicilluscapitatus. J Nat Prod 2006;69:542-6. 
11. Harada H, Noro T, Kamei Y. Selective antitumor activity in vitro from marine algae from Japan coast. Biol Pharm Bull 1997;20:541-6.

12. Xu H, Yao L, Sung H, Wu L. Chemical composition and antitumor activity of different polysaccharides from the roots of Actinidiaeriantha. Carbohydr Pol 2009;78:316-22.

13. RA Lincoln, K Strupinski, JM Walker. Bioactive compounds from algae. Life Chem Rep 1991;8:97-183.

14. Adams NM. Seaweeds of New Zealand: An Illustrated Guide. Canterbury University Press: Christchurch, New Zealand; 1994.

15. Fadli M, Aracil JM, Jeanty G, Banaigs B, Francisco C. Novel Meroterpenoids from Cystoseiramediterranea: use of the crown-gall bioassay as a primary screen for lipophilic antineoplastic agents. J Nat Prod 1991;54:261-4.
16. Gonzalez AG, Darias V, Estevez E. Chemotherapeutic activity of polyhalogenated terpenes from Spanish algae. Planta Med 1997:44:44-6.

17. Mosmann T. Rapid colorimetric assay for cellular growth and survival: application to proliferation and cytotoxicity assays. J Immunol Methods 1983;65:55-63.

18. Gross H, Goeger DE, Hills P, Mooberry SL, Ballantine DL, Murray TF, et al. "Lophocladines, bioactive alkaloids from the red alga Lophocladia sp." J Nat Prod 2006;69:6404.

19. Smit AJ. Medicinal and pharmaceutical uses of natural seaweed products: a review. J Appl Phycol 2004;16:245-62.

\section{How to cite this article}

- Ashwini S, Suresh Babut V, Saritha, Manjula Shantaram. Seaweed extracts exhibit anticancer activity against HeLa cell lines. Int J Curr Pharm Res 2017;9(1):114-117. 